Tjalling C. Koopmans Research Institute Tplligh Aoopman

Discussion Paper Series nr: 04-11

\title{
Strategic Delegation of Environmental Policy Making
}

Hein Roelfsema 


\section{Tjalling C. Koopmans Research Institute Utrecht School of Economics \\ Utrecht University}

Vredenburg 138

3511 BG Utrecht

The Netherlands

telephone $\quad+31302539800$

fax $\quad+31302537373$

website www.koopmansinstitute.uu.nl

The Tjalling C. Koopmans Institute is the research institute and research school of Utrecht School of Economics.

It was founded in 2003, and named after Professor Tjalling C. Koopmans, Dutch-born Nobel Prize laureate in economics of 1975.

In the discussion papers series the Koopmans Institute publishes results of ongoing research for early dissemination of research results, and to enhance discussion with colleagues.

Please send any comments and suggestions on the Koopmans institute, or this series to P.vanDriel@econ.uu.nl

ontwerp voorblad: WRIK Utrecht

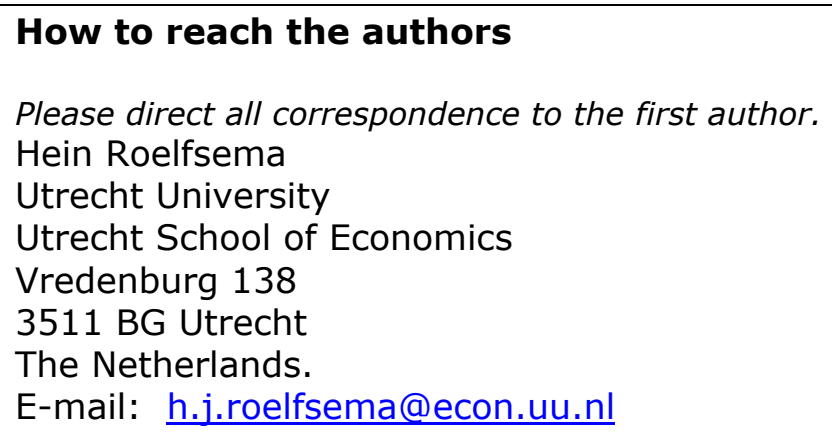

This paper can be downloaded at: http://www.koopmansinstitute.uu.nl 
Utrecht School of Economics

Tjalling C. Koopmans Research Institute

Discussion Paper Series 04-11

\title{
Strategic Delegation of Environmental Policy Making
}

\author{
Hein Roelfsema \\ Utrecht School of Economics \\ Utrecht University
}

January 2004

\begin{abstract}
A common claim is that nations should cooperate in environmental policy making. However, there is little empirical support that noncooperative decision making results in too low environmental standards and taxes. We develop a theoretical model and show that if the median voter cares sufficiently for the environment, she has an incentive to delegate policy making to a politician that cares more for the environment than she does herself. By doing so, she mitigates the 'race to the bottom' in environmental taxes. In contrast, if environmental policies are determined cooperatively with other countries, the median voter has an incentive to delegate policy making to a politician that cares less for the environment than she does herself, so as to free ride on international environmental agreements.
\end{abstract}

Keywords: environmental policy, international policy coordination, strategic delegation.

JEL classification: $F 12, F 18, H 77$, Q2

\section{Acknowledgements}

I thank Klaas Beniers, Harry Garretsen, Amihai Glazer, Otto Swank, participants at the Public Choice Society meeting in Nashville, the European Public Choice Society in Arhus and the Silvaplana Public Economics meetings for comments on earlier drafts. I thank Robert Dur for supervising the paper. 


\section{Introduction}

A common fear is that free trade erodes the environment. More trade means more production and the pollution that comes along with this causes the environment to degenerate. Moreover, it is argued that the reduction of barriers to trade gives governments an incentive to impose laxer environmental regulation, so as to establish a cost advantage for domestic firms. Free trade may therefore lead to a 'race to the bottom' of taxes on pollution and of emission standards. To counter the competitive introduction of lenient policies and to avoid the decay of the environment, it is often claimed that governments should cooperate in implementing environmental policies. ${ }^{1}$

However large the potential threat of a race to the bottom may be in theory, there is little empirical support for the claim that non-cooperative environmental policy making leads to lenient policies (Antweiler et al. 2001, Wang and Winters 2001). Further, in many cases where countries are engaged in environmental policy cooperation, the results have failed to impress. For instance, Congleton (2001) investigates the history of environmental treaties and concludes that most have little substance and are merely symbolic.

This paper develops a theoretical model to analyze environmental policy making, both in a non-cooperative and in a cooperative setting. First, we show that non-cooperative policy making does not necessarily lead to a race to the bottom in environmental taxes. Building on the citizen-candidate approach pioneered by Besley and Coate (1997), we demonstrate that if the median voter cares sufficiently for the environment and anticipates lenient policies, she may have an incentive to delegate policy making authority to a politician who cares more for the environment than she does herself. By doing so, she commits to higher domestic taxes which potentially shifts production to foreign countries. If the foreign policy maker cares sufficiently for

\footnotetext{
${ }^{1}$ Surveys on the apparent tension between free trade and environmental protection are provided by Wilson (1996) and Esty (2001). See Copeland and Taylor (2003) for an extensive theoretical review of the literature.
} 
the environment as well, this raises optimal equilibrium taxes in the foreign country as well. Hence, by delegating policy making authority, the domestic median voter obtains a cleaner local environment and avoids part of the loss in market share that results from high domestic environmental taxes. In the symmetric equilibrium, the delegation effect mitigates the race to the bottom.

We continue to show that cooperation does not necessarily bring about optimal environmental policies. The median voter anticipates that cooperation implies too stringent domestic environmental policies, as it internalizes the competition externality on the other country. Therefore, she has an incentive so as to improve the centralized policy outcome from the domestic perspective by delegating policy making to a politician that cares less for the environment than she does herself. By doing so, she obtains a lower tax rate for the domestic industry if compared to the other country and, hence, higher profits for the domestic firm. In the symmetric equilibrium policy cooperation results in a sub-optimally low level of environmental taxes. Furthermore, when median voters care strongly for the environment, we are able to show that cooperation may reduce environmental taxes if compared to non-cooperative policy making.

The model revolves around two identical countries in which firms produce a homogeneous good. In the world market, these firms are engaged in Cournot competition. Production causes local pollution only. Given the policies in the other country, lower environmental taxes shift rents to the domestic firm, thereby increasing domestic welfare. However, a lower tax level raises home production which deteriorates the local environment. Citizens differ in their preferences for the environment. The winner of the elections is the politician whose policy preferences maximize the utility of the median voter. In the non-cooperative setting, the policy maker imposes environmental taxes without taking account of the welfare effects in other countries. When policy makers cooperate, they formulate environmental policies to maximize their 
collective welfare.

There is a considerable body of literature on the political economics of environmental policy making. One branch is in the Brander and Spencer (1985) strategic trade tradition and shows that non-cooperative policy making results in too low environmental taxes (e.g. Barrett 1994, Kennedy 1994, and Ulph 1996). In these papers, as in ours, the implicit reason for cooperation is that countries are engaged in environmental "beggar thy neighbor" games in which, in the end, no firm gains market share, while at the same time the environment deteriorates. As the policy maker in these papers is a social planner, cooperation would lead to socially optimal environmental policies.

Another branch examines the effects of lobbying on environmental policy making. ${ }^{2}$ Most of this growing literature makes use of the Grossman and Helpman (1994) work-horse model (e.g. Aidt 1998, Fredriksson 1997, Schleich 1999). ${ }^{3}$ The main result of this literature is that policy makers are willing to set inefficiently low environmental taxes to attract political contributions from organized producer interest groups. To our knowledge, no contribution in this approach has so far taken account of international cooperation in environmental policy making. ${ }^{4}$

The main contribution of this paper is that, by introducing an electoral process, we are able to show that in some cases non-cooperative decision making produces good results, while cooperation may lead to disappointment. The spirit of our model is close to Besley and Coate (2003). They show, by allowing for strategic delegation in centralized decision making on local public goods, that the median voter in each jurisdiction has an incen-

\footnotetext{
${ }^{2}$ See Oates and Portney (2001) for a survey.

${ }^{3}$ See for an alternative approach Hillman and Ursprung (1994).

${ }^{4}$ However, in a trade policy context, Grossman and Helpman (1995) extend their model to account for non-cooperative interaction (wars) as well as cooperative interaction (talks) between governments. This extension shows that cooperation among policy makers may reduce policy distortions because it pits the sector lobby groups in one country against the lobby groups in the other country.
} 
tive to misrepresent her preferences by electing a federal representative who cares more for local public goods than she does herself. Hence, in the symmetric equilibrium the federal legislature supplies an inefficiently high level of local public goods. Dur and Roelfsema (2002) build on this to show that high non-shared costs of public goods provision induce voters to delegate to conservative representatives, resulting in an undersupply of public goods.

Our model provides a theoretical foundation for recent empirical studies that fail to find evidence for a race to the bottom when policies are set non-cooperatively. In addition to the contributions mentioned earlier, Hoel (1991) analyzes unilateral actions of countries in setting environmental taxes and concludes that, even in a non-cooperative environment, some countries go to great lengths to preserve the environment. As an example, he notes that Norway strongly reduced CFC-emissions in the years before the Montreal-agreement. Murdoch and Sandler (1997) show that even though the Montreal Protocol on CFC reduction provided for a cooperative negotiating framework, the resulting reductions for many countries are no different than those that would have appeared in a non-cooperative Nash equilibrium. As a further example, List and Gerking (2000) show that environmental quality in the US did not decline under the Reagan presidency. This is remarkable because Reagan's new federalism shifted environmental policy making back to the state level. In this new, non-cooperative environment, one might expect environmental quality to decline. However, the authors show that environmental quality did in fact improve in the 1980s.

Lastly, Fredriksson and Millimet (2002) provide evidence that the response of states in the US to changes in environmental regulation of their neighbors is asymmetric. They show that states follow their neighbors in raising standards if these standards are already stringent. Thus, in the NorthEast and West of the US non-cooperative policy making leads to high levels of environmental standards. This confirms our finding that in rich states, where the median voter has strong preferences for environmental quality, 
non-cooperative policy making may lead to strong environmental protection. In other areas, like the relatively poor Mid-West and South, this effect does not occur.

The paper is organized as follows. In Section 2 we introduce the basic model. In Section 3 we examine environmental taxes if policies are set by median voters. Section 4 introduces strategic delegation of policy making. Section 5 evaluates the welfare effects of the various political decision making settings. Section 6 offers some final remarks.

\section{The Model}

Consider two identical countries $i, i \in\{h, f\}$, where $h$ should be read as 'home' and $f$ as 'foreign'. Each country has one firm that produces a homogeneous good $Q$. Production of the home (foreign) firm is denoted by $q_{h}\left(q_{f}\right)$. We assume that each of the firms exports $q_{i}$ to a third market only, that we call "the world market" for simplicity. ${ }^{5}$ In this world market, the two firms are engaged in Cournot competition. Inverse demand $P(Q)$ is given by:

$$
P(Q)=1-Q
$$

Production causes local emissions $e_{i}$. These emissions increase linearly in production with slope one. Further, without loss of generality (as firms are identical) direct production costs are normalized to zero. ${ }^{6}$

Define the total tax costs of the local firm as $T_{i}=t_{i} q_{i}$. If $t_{i}>0$, the firm pays a tax for the production of each unit of $q_{i}$; if $t_{i}<0$ the firm receives a

\footnotetext{
${ }^{5}$ By making this assumption we exclude policy effects on the domestic and foreign consumer surplus. This enables us to concentrate on the capture of rents.

${ }^{6}$ This excludes the cases where environmental degradation results from buying inputs at too low prices. See Aidt (1998) for a political economics discussion on the difference between input and production taxes.
} 
per unit subsidy. The profits $\Pi_{i}$ of the firm in $i$ are given by:

$$
\Pi_{i}=P(Q) q_{i}-T_{i}
$$

The Cournot-Nash quantity produced by the home and foreign firm are:

$$
\begin{aligned}
q_{h} & =\frac{1+t_{f}-2 t_{h}}{3} \\
q_{f} & =\frac{1+t_{h}-2 t_{f}}{3}
\end{aligned}
$$

The home firm's production is decreasing in the tax rate in home and increasing in tax rate in foreign. ${ }^{7}$ A lower home tax rate reduces the marginal cost of production of the home firm. Given the output decision of the foreign firm, this results in an increase in production. Further, an increase in the foreign tax results in a fall in foreign supply, which raises the price on the on the world market which raises the optimal level of production.

The typical citizen in $i$ derives income from two sources. First, all citizens have an equal share in the profits of the domestic firm. Second, in the case of a production tax, each citizen receives a lump sum government transfer out of the tax revenues. In the case of a production subsidy, citizens pay an equal per capita lump sum tax to finance this policy.

Citizens attach cost to local environmental degradation that is caused by production. These costs are given by the convex damage function $D\left(e_{i}\right)=$ $\frac{1}{2} e_{i}^{2}$. Citizens have heterogeneous preferences for a clean environment. Let the parameter $\lambda_{i}^{j} \in\left\{0, \lambda_{i}^{\max }\right\}$ measure the strength of these preferences of individual $j$ in $i$ relative to income, where $\lambda$ is distributed symmetrically over the population. This assumption allows us to use the utility of the median voter as a measure for social welfare. The preferences of the median voter $\left(\lambda_{i}^{m}\right)$ are common knowledge.

\footnotetext{
${ }^{7}$ There is a related literature on the effects of environmental regulation on plant location (e.g. Levinson 1996). Production levels may loosely be associated with location decisions, as home and foreign production levels are determined in the last stage of the game.
} 
The indirect utility function $V_{i}^{j}$ of an individual $j$ in country $i$ is:

$$
V_{i}^{j}=\Pi_{i}+T_{i}-\lambda_{i}^{j} D\left(e_{i}\right)
$$

In this set up, there are two reasons for governments to influence firm behavior. First, emissions are an externality, so, without intervention, the export revenues do not reflect the social costs of production. This gives each policy maker an incentive to impose an environmental tax on the production of $Q$. Second, as is standard in strategic trade theory, if firms are engaged in Cournot competition, each policy maker has an incentive to subsidize domestic production. Thus, in setting the optimum non-cooperative environmental policy, the policy maker faces a trade off between the domestic firm's profits and the quality of the local environment.

To provide a benchmark for the political economy results, in the next section we first examine the policies that would result when citizens vote non-strategically. In this case, the person with the median preferences for the environment implements policies. We study two political decision making systems. The first is where policies are set non-cooperatively. The second is where policies are set cooperatively with other countries. Throughout the paper we assume that cooperation means that policy makers maximize their joint welfare. ${ }^{8}$ Because voter's preferences are symmetrically distributed, the cooperative policy is identical to the social optimum.

In the remaining sections we then continue to consider strategic delegation. Here, the median voter recognizes that delegating policy making to a person whose preferences differ from that of her own may bring benefits in the form of higher firm profits or a cleaner environment if compared to the situation in which she herself is a policy maker. By delegating policy making strategically, the median voter commits to a policy stance which would not be credible if she would set policy herself. Here again we consider the

\footnotetext{
${ }^{8}$ By restricting attention to equilibria that maximize the joint surplus, we follow Besley and Coate (2003) .
} 
non-cooperative and the cooperative cases.

\section{$3 \quad$ Sincere Voting}

We start with the non-cooperative case. The first-order condition for the policy maker in home (the foreign case is similar) is:

$$
\frac{\partial V_{h}^{m}}{\partial t_{h}}=\left[\frac{\partial R_{h}}{\partial t_{h}}-\frac{\partial T_{h}}{\partial t_{h}}\right]+\frac{\partial T_{h}}{\partial t_{h}}-\lambda_{h}^{m} \frac{\partial D\left(e_{h}\right)}{\partial t_{h}}=0
$$

Condition (6) shows that a change in the tax rate has two effects. First, given the policies in the foreign country, a change in the tax/subsidy rate influences the revenues $R_{h}$ of the domestic firm. Second, an increase in the tax rate reduces domestic production and, hence, local damage from emissions. Furthermore, because tax collection is assumed to be costless, the change in the firm's tax payments equals the change in government transfers. Using (3) and (4), and recalling the linear relation between output and emission $q_{h}=e_{h}$, the first-order condition (6) can be written as:

$$
\left(1+4 t_{h}+t_{f}\right)-2 \lambda_{h}^{m}\left(1-2 t_{h}+t_{f}\right)=0
$$

Combining the first-order conditions for optimal policies in home and foreign yields the non-cooperative equilibrium level of the home and foreign taxes:

$$
\begin{aligned}
& t_{h}=\frac{\left(2 \lambda_{h}^{m}-1\right)\left(2 \lambda_{f}^{m}+1\right)}{6 \lambda_{h}^{m}+6 \lambda_{f}^{m}+4 \lambda_{h}^{m} \lambda_{f}^{m}+5} \\
& t_{f}=\frac{\left(2 \lambda_{f}^{m}-1\right)\left(2 \lambda_{h}^{m}+1\right)}{6 \lambda_{f}^{m}+6 \lambda_{h}^{m}+4 \lambda_{f}^{m} \lambda_{h}^{m}+5}
\end{aligned}
$$

Clearly, in (8) $\frac{\partial t_{h}}{\partial \lambda_{h}^{m}}>0$ : stronger home median preference for the environment increase the optimal tax level. According to (9), the effects of a change in the preferences of the home policy maker are ambiguous. If $\lambda_{f}^{m}>\frac{1}{2}$, then 
$\frac{\partial t_{f}}{\partial \lambda_{h}^{m}}>0$; if the foreign median voter has sufficiently strong preferences for the environment, an increase in the preference of the home median voter for the environment raises the optimal level of foreign taxes. The reason is that an environmental friendly foreign policy has a strong desire to counter the resulting increase in pollution, as the home firm reduces production and the foreign firm increases production.

In contrast, when the foreign median preferences for the environment are weak $\left(\lambda_{f}^{m}<\frac{1}{2}\right)$ and, hence, the foreign policy maker cares much for profits, stronger home median preferences go together with lower optimal foreign taxes. Stronger home preferences reduce home output, which, for each level of output by the foreign firm, raises prices on the world market. When the foreign policy maker cares less form the environment and thus much for profits, she has an incentive to further increase foreign production. Hence, the optimal tax level in foreign country is lower.

In the symmetric equilibrium $\left(\lambda_{h}^{m}=\lambda_{f}^{m}\right)$ the non-cooperative tax/subsidy rate equals:

$$
t_{i}^{n c}=\frac{2 \lambda_{i}^{m}-1}{2 \lambda_{i}^{m}+5}
$$

If median preferences for the environment are sufficiently weak $\left(\lambda_{i}<\frac{1}{2}\right)$, both countries give subsidies: the strategic trade policy objective overshadows the concern for environmental degradation. If median preferences for a clean environment are sufficiently strong $\left(\lambda_{i}>\frac{1}{2}\right)$, the opposite happens and both countries impose environmental taxes.

The resulting taxes are always too low if compared to the cooperative tax level that maximizes joint welfare $V^{c}=V_{h}^{m}+V_{f}^{m}$. The home tax level that maximizes joint welfare follows from:

$$
\frac{\partial V^{c}}{\partial t_{h}}=\left[\frac{\partial R_{h}}{\partial t_{h}}+\frac{\partial R_{f}}{\partial t_{h}}\right]-\lambda_{h}^{m} \frac{\partial D\left(e_{h}\right)}{\partial t_{h}}-\lambda_{f}^{m} \frac{\partial D\left(e_{f}\right)}{\partial t_{h}}=0
$$


Again using (3) and (4) this can be written as:

$$
\left(1-2 t_{h}-2 t_{f}\right)-2 \lambda_{h}^{m}\left(2 t_{h}-t_{f}-1\right)-\lambda_{f}^{m}\left(t_{h}-2 t_{f}+1\right)=0
$$

The first term on the left shows the joint marginal revenue of a change in the home tax rate. It is easy to see that joint revenue of the firms is maximized if both countries set export taxes $t=\frac{1}{4} \cdot{ }^{9}$ The second and third term are the increase in environmental quality in home and foreign.

Using the first-order conditions for both $t_{h}$ and $t_{f}$ and imposing symmetry in equilibrium gives the cooperative level of taxes:

$$
t_{i}^{c}=\frac{\lambda_{i}^{m}+1}{\lambda_{i}^{m}+4}
$$

The tax rate in home and foreign is positive for any level of the preferences of the median voters for two reasons. First, imposing taxes increases the joint revenue of the firms. Even in the limiting case where $\lambda_{i}^{m}=0$, the optimal tax rate is $t_{i}=\frac{1}{4}$ so as to maximize the terms of trade gains. Second, taxes reduce production and, hence, pollution. Stronger preferences of the median voter for the environment raise the equilibrium tax rate above $\frac{1}{4}$, and, hence, reduce output below the monopoly level. Comparing (13) and (10) it follows that the non-cooperative tax level is lower than the socially optimal level.

\section{Political Decision Making}

In this section citizens strategically select a politician to whom they delegate environmental policy making. When evaluating the candidates, voters take account of how the preferences of each candidate will ultimately affect their utility. The electoral process is modelled as a citizen-candidate procedure.

\footnotetext{
${ }^{9}$ Note that if $t_{i}=\frac{1}{4}$, the production of each firm is $q_{i}=\frac{1}{4}$, which gives the monopoly output $Q=\frac{1}{2}$. This result is familiar in the literature on strategic trade policy, see Brander and Spencer (1985).
} 
Each individual $j$ in $i$ is available for office in $i$, all citizens vote, there are no costs of running for office and there are no costs of voting. ${ }^{10}$ The person who is able to obtain the majority of votes in an electoral contest against any other individual in society wins. The familiar outcome from this procedure is that the candidate is elected whose preferences maximize the utility of the median voter. Elected politicians are assumed to be outcome-motivated only.

\subsection{Non-Cooperative Decision Making}

In a non-cooperative policy making setting, the timing of events is as follows. In the first stage the voters in home and foreign elect a policy maker. In the second stage each of these two policy makers non-cooperatively implements the environmental policy that maximizes her own welfare. In stage three firms make their output decisions.

In the third stage firms in home and foreign set their production according to (3) and (4). In the second stage, both policy makers set tax rates that maximize (5). Hence, in equilibrium the home output level is described by:

$$
q_{h}=\frac{2\left(1+2 \lambda_{f}^{p}\right)}{5+6 \lambda_{h}^{p}+6 \lambda_{f}^{p}+4 \lambda_{h}^{p} \lambda_{f}^{p}}
$$

where $\lambda_{i}^{p}$ are the preferences of the policy maker in country $i$. In the first stage the problem for the median voter in each country is to select the candidate that maximizes her utility. Using (5), the first-order condition for the median voter in home is:

$$
\frac{\partial V_{h}^{m}}{\partial \lambda_{h}^{p}}=\frac{\partial R_{h}}{\partial q_{h}} \frac{\partial q_{h}}{\partial \lambda_{h}^{p}}+\frac{\partial R_{h}}{\partial q_{f}} \frac{\partial q_{f}}{\partial \lambda_{h}^{p}}-\lambda_{h}^{m} \frac{\partial D\left(e_{h}\right)}{\partial q_{h}} \frac{\partial q_{h}}{\partial \lambda_{h}^{p}}=0
$$

\footnotetext{
${ }^{10} \mathrm{By}$ making the assumption that each citizen is a candidate, we debar the abstention effect as studied by Laussel and Riezman (2002). They argue that the optimal candidate may strategically decide not to enter, which may force the median voter to pick an even more extreme person.
} 
Solving the first-order conditions for $\lambda_{i}^{p}$ and imposing symmetry $\left(\lambda_{h}^{p}=\lambda_{f}^{p}\right)$ in equilibrium results in an optimum policy maker with preferences for the environment:

$$
\lambda_{i}^{p}=\frac{1}{2}\left[\lambda_{i}^{m}-1+\sqrt{\lambda_{i}^{m}\left(\lambda_{i}^{m}+4\right)}\right]
$$

First note that the median voter only delegates policy making to a politician with the same preferences if $\lambda_{i}^{m}=\frac{1}{2}$. In that case - as follows from (10) the policy maker imposes zero taxes on production. If the median voter has weak preferences for the environment $\left(\lambda_{i}^{m}<\frac{1}{2}\right)$, she delegates policy making to a person that has even weaker preferences for the environment than those of her own. If, on the other hand, the median voter has strong preferences for the environment $\left(\lambda_{i}^{m}>\frac{1}{2}\right)$, she delegates policy making to a politician that cares more for the environment than she does herself.

The intuition behind these results is the following. Suppose that both median voters are in office. If in both countries $\lambda_{i}^{m}<\frac{1}{2}$, delegating policy making to a person that cares even less for the environment servers as a credible commitment to increase subsidies. Given that the policy maker in foreign cares much for profits of the foreign firm, this, according to (8), decreases subsidies in foreign. Hence, the commitment to higher home subsidies shifts rents to the home firm. From the perspective of the home median voter, the negative effect of higher home subsidies on the local environment is more than compensated for by the increase in profits of the home firm. As both median voters have this incentive for strategic delegation, the political equilibrium subsidies are higher than those that median voter would set themselves.

In contrast, if both median voters sufficiently care for the environment $\left(\lambda_{i}^{m}>\frac{1}{2}\right)$, delegating policy making to a politician that cares even more for the environment increases taxes in the home country and in the foreign country. The reason is that the environmental friendly foreign median voter dislikes the increase in pollution that results from higher foreign output, 
which gives her an the incentive to impose a higher tax as well. This increases the utility of the home median voter because the negative effects of high domestic taxes on the revenues of the home firm are partly offset by high foreign taxes. At the same time, higher taxes improve the local environment. In the symmetric equilibrium both median voters delegate policy making to policy makers that care more for the environment than they do themselves, which results in a 'race to the top' in environmental policy making. ${ }^{11}$

\subsection{Cooperative Political Decision Making}

In section 3 it was assumed that when median voters cooperatively set environmental policy, they choose to maximize their joint welfare. However, recall that although policies are set by joint consent, they need not be uniform. ${ }^{12}$ Hence, the median voter can select the preference profile of 'her' politician, so as to influence policies that result from cooperative decision making. For example, the median voter may anticipate that selecting a person with lower preferences for the environment than the policy maker in the foreign country results in a lower tax for the domestic industry.

Using (11), the optimum tax rate in home that results from cooperative decision making is:

$$
t_{h}=\frac{\lambda_{h}^{p}\left(1+\lambda_{f}^{p}\right)}{2 \lambda_{h}^{p}+2 \lambda_{f}^{p}+\lambda_{f}^{p} \lambda_{h}^{p}}
$$

Clearly, the equilibrium home tax rate is increasing in $\lambda_{h}^{p}$. Following the same procedure as in section 4.1, the equilibrium preferences of the policy maker are given by (15). In the symmetric equilibrium the characteristics of

\footnotetext{
${ }^{11}$ In political science, where it is known as the California effect, there are many casestudy testimonies of a race to the top in non-cooperative policy making. Vogel (1995), to whom the term 'race to the top' is attributed, describes the mechanisms through which higher environmental standards in one nation may increase those in others.

${ }^{12}$ In many international environmental treaties, like in the Montreal and Kyoto protocol, environmental commitments and their resulting targets are country specific.
} 
the optimum policy maker are:

$$
\lambda_{i}^{p}=\frac{1}{2} \lambda_{i}^{m}-\frac{3}{2}+\frac{1}{2} \sqrt{\left(\lambda_{i}^{m}\right)^{2}+2 \lambda_{i}^{m}-7}
$$

For all cases other than $\lambda_{i}^{m} \rightarrow \infty$ the median voter delegates policy making to a politician that cares less for the environment than she does herself. For the intuition of this result, suppose that median voters with $\lambda>0$ are policy makers. In that case the equilibrium tax rate of $t>\frac{1}{4}$ strongly reduces exports to the world market and, hence, raises world market prices to a level for which the marginal firm revenues are higher than the marginal environmental damage costs to the local economy. Thus, the median voter in home will be better of by obtaining a lower tax rate for the domestic firm. Hence, the median voter has an incentive to delegate policy making to persons that care less for the environment than she does herself. By doing so, given the centralized bargaining structure, she receives lower tax rate for the domestic firm.

What is the optimal delegation decision for the median voter? For sufficiently low levels of home preferences $\left(\lambda_{m}^{i}<2\right)$, the optimal strategy is to delegate policy making to a person who cares slightly less for the environment than the policy maker in the foreign country. The intuition is that for all centralized tax levels $t>\frac{1}{2}$ the marginal benefits of obtaining a lower tax level for the domestic industry are higher than the marginal damage costs. Hence, for $\lambda_{m}^{i}<2$ this Bertrand-type of delegation game results in both median voters delegating to policy makers that have $\lambda_{p}^{i}=0$, as this would produce $t=\frac{1}{4}$. Only extreme lovers of the environment (according to (18) those with $\lambda_{i}^{m} \geq 2$ ) may want to delegate policy making to policy makers that have a non-zero valuation for the environment. However, also in this last case the selected policy maker cares less for the environment than the median voter does herself. 


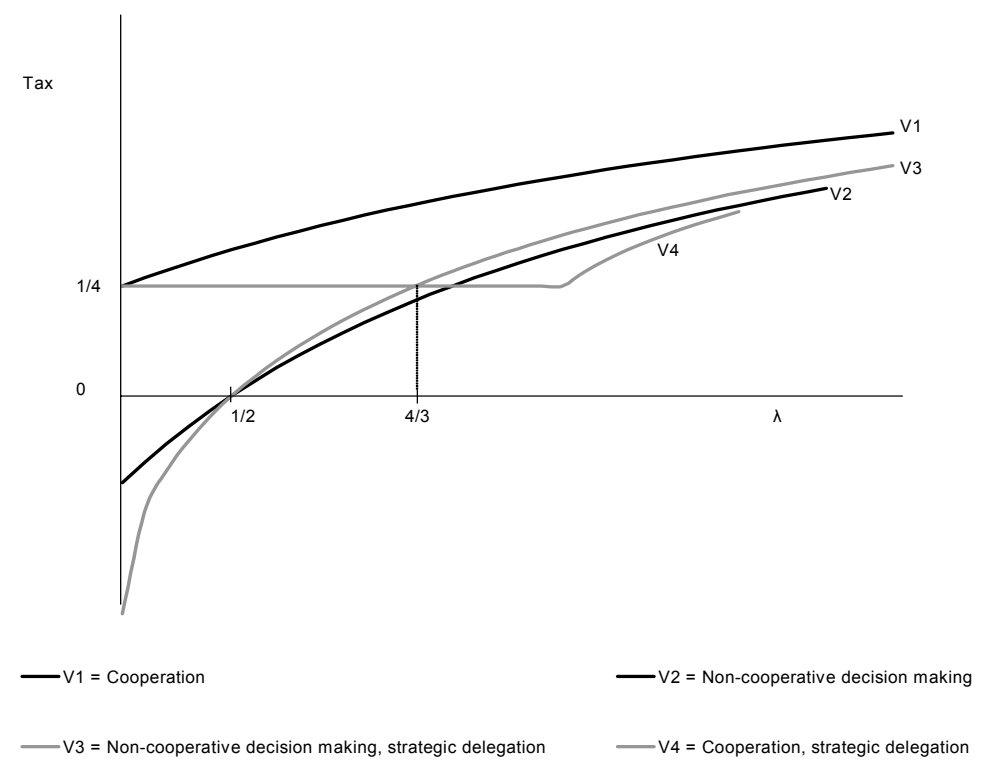

Figure 1:

\section{Welfare Analysis}

This section compares, evaluates and summarizes the results of the previous sections. We focus on two features. First, we compare the political decision making outcomes of Section 4 to the decentralized and to the joint welfare maximizing policies derived in Section 3. Second, we compare cooperative to non-cooperative policy making in the presence of strategic delegation. Figure 1 shows the equilibrium tax outcomes of the previous sections.

It is immediately clear that taxes in all cases are always too low if compared to the cooperative tax level with sincere voting (V1). Therefore, both non-cooperative (sincere and strategic) as well as strategic delegation in a cooperative setting result to some extent in a race to the bottom.

Comparing the curves for non-cooperative decision making (V2 and V3) show that if the median voters would opt for subsidies on polluting goods 
$(t<0)$, strategic voting magnifies the race to the bottom effect: both median voters commit to higher subsidies by voting in office policy makers that care less for the environment than they do themselves, thereby increasing polluting subsidies. This implies that when both median voters have weak preferences for environmental quality, strategic delegation of policy making moves the equilibrium away from the socially optimal policy as described by V1. The opposite result arises if the median voters have strong preferences for the environment. If $\lambda_{i}>\frac{1}{2}$, the median voter selects a politician who has stronger preferences for the environment than those of her own. Because strategic delegation pushes equilibrium taxes upwards, it increases welfare when compared to the situation where median voters implement policies themselves.

Comparing the curves for cooperative policy making (V1 and V4), strategic voting (V4) reduces environmental taxes if compared to sincere voting (V1). Recall that from equation (18) it follows that if policies are coordinated, persons with $\lambda<2$ vote for a candidate that has preferences of $\lambda=0$. Because both countries appoint persons that do not care for the environment at all, strategic delegation moves taxes away from the socially optimal level.

Comparing non-cooperative to cooperative political decision making in the presence of strategic voting (V3 to V4), it becomes clear that effects of cooperation on social welfare are ambiguous. For low and moderate preferences for the environment $\left(0 \leq \lambda_{i} \leq \frac{4}{3}\right)$ cooperation improves welfare. Two opposing effects of cooperation influence the equilibrium level of taxes. First, cooperation increases the optimal tax level as policy makers exploit the terms of trade effect and "prey" on the third country. Second, however, both median voters realize that the domestic tax rate resulting from cooperation will be too high. Therefore, the median voters have an incentive to elect a politician who has lower preferences for the environment than those of their own. This last effect pulls the political equilibrium tax down. ${ }^{13}$ In the interval

\footnotetext{
${ }^{13}$ Notice that the reversal in the delegation decision is particular dramatic in the interval
} 
$0 \leq \lambda_{i} \leq \frac{4}{3}$ the net effect of cooperation is an increase in taxes, which is welfare improving in home and foreign.

An intriguing result arises if the median voters have (very) strong preferences for the environment $\left(\lambda_{i}>\frac{4}{3}\right)$. In that case, cooperation brings about lower environmental taxes, as the strategic delegation effect (which lowers taxes) overshadows the effect that the negative spill-overs of Cournot competition are internalized (which raises taxes).

\section{Concluding Remarks}

We argue that strategic voting may explain the sometimes surprisingly good results of non-cooperative environmental policy making. In a non-cooperative policy making setting, voters may have an incentive to elect persons that are stronger supporters of green policies than they are themselves. Second it provides an explanation why cooperation often disappoints. If voters anticipate cooperative policy making, they have an incentive to vote for politicians that care less for the environment than they do.

The paper could be extended in several interesting ways. First, as yet there are no pollution spillovers. Trans-boundary externalities are a major impetus for conducting international environmental treaties. We may speculate that these negative externalities in our model reduce the incentives for strategic delegation as pollution shifting becomes less 'profitable'. Second, competitors on the world market could be incorporated. Esty and Geradin (1997) argue that the external competitiveness is a major issue in the negotiations over regionally coordinated environmental policies. Speculating again, we may expect that external competition reduces the terms of trade gains from taxation and, hence, significantly alters the benefits from delegation.

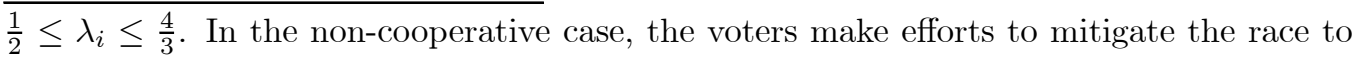
the bottom effect by electing policy makers that care more for the environment than they do, so as to make a credible commitment to greener policies. In the cooperative case, median voters nevertheless may have better policies by "worse" politicians. 
Third, we focus on symmetric equilibria. However, some regional integration initiatives accommodate countries that differ in their level of economic development, comparative advantages, and industry structure and, hence, have heterogeneous preferences for environmental protection. For instance, Aidt and Greiner (2002) show that the burden of reducing greenhouse emissions under the Kyoto protocol is distributed among EU members in accordance with their preference for environmental protection, whereby low income countries are allocated less stringent reduction targets. Finally, some insights of this paper may be applicable in other policy domains where the theoretical argument for a race to the bottom seems apparent, like tax competition and the coordination of migration issues.

\section{References}

Aidt, T. (1998). Political internationalization of economic externalities and environmental policy. Journal of Public Economics 69(1), 1-16.

Aidt, T. and S. Greiner (2002). Sharing the climate burden in the EU. HWWA Diskussionspapier Nr. 176, Hamburg.

Antweiler, W., W. Copeland, and M. Taylor (2001). Is free trade good for the environment? American Economic Review 91(4), 877-908.

Barrett, S. (1994). Strategic environmental policy and international trade. Journal of Public Economics 54(3), 325-338.

Besley, T. and S. Coate (1997). An economic model of representative democracy. Quarterly Journal of Economics 112(1), 85-114.

Besley, T. and S. Coate (2003). Centralized versus decentralized provision of local public goods: A political economy analysis. Journal of Public Economics 87(12), 2611-2637.

Brander, J. and B. Spencer (1985). Export subsidies and market share rivalry. Journal of International Economics 18, 83-100. 
Congleton, R. (2001). The political economy of international environmental treaties and institutions. In G. Schulze and H. Ursprung (Eds.), International environmental economics: A survey of the issues, Oxford and New York. Oxford University Press.

Copeland, B. and M. Taylor (2003). Trade, growth and the environment. NBER working paper 9823, Cambridge, MA.

Dur, R. and H. Roelfsema (2002). Why does centralisation fail to internalise policy externalities? Tinbergen Research Papers 02-056/3, Rotterdam.

Esty, D. and D. Geradin (1997). Market access, competitiveness, and harmonization: environmental protection in free trade agreements. Harvard Environmental Law Review 21, 265-336.

Esty, D. C. (2001). Bridging the trade-environment divide. Journal of Economic Perspectives 15(3), 113-130.

Fredriksson, P. G. (1997). The political economy of pollution taxes in a small open economy. Journal of Environmental Economics and Management 33(1), 44-58.

Fredriksson, P. G. and D. L. Millimet (2002). Strategic interaction and the determination of environmental policy across US states. Journal of Urban Economics 51(1), 101-122.

Grossman, G. M. and E. Helpman (1994). Protection for sale. American Economic Review 84(4), 833-850.

Grossman, G. M. and E. Helpman (1995). Trade wars and trade talks. Journal of Political Economy 103(4), 675-708.

Hillman, A. and H. Ursprung (1994). The influence of environmental concerns on the political determination of trade policy. In K. Anderson and R. Blackhurst (Eds.), The Greening of World Trade Issues, New York. Harvester Wheatsheaf. 
Hoel, M. (1991). Global environmental problems: The effects of unilateral actions taken by one country. Journal of Environmental Economics and Management 20, 55-70.

Kennedy, P. W. (1994). Equilibrium pollution taxes in open economies with imperfect competition. Journal of Environmental Economics and Management 27(1), 49-63.

Laussel, D. and R. Riezman (2002). The sources of protectionist drift in representative democracies. Center for Economic Studies Working Paper, Munich.

Levinson, A. (1996). Environmental regulation and industry location: International and domestic evidence. In J. Bhagwati and R. Hudec (Eds.), Fair Trade and Harmonization: Prerequisites for free trade, Cambridge, MA. MIT Press.

List, J. A. and S. Gerking (2000). Regulatory federalism and environmental protection in the United States. Journal of Regional Science 40(3), 453-471.

Murdoch, J. C. and T. Sandler (1997). The voluntary provision of a pure public good: The case of reduced CFC emissions and the Montreal Protocol. Journal of Public Economics 63(3), 331-349.

Oates, W. E. and P. R. Portney (2001). The political economy of environmental policy. Resources For The Future Discussion Paper 01-55, Washington.

Schleich, J. (1999). Environmental quality with endogenous domestic and trade policies. European Journal of Political Economy 15, 53-71.

Ulph, A. (1996). Environmental policy and international trade when governments and producers act strategically. Journal of Environmental Economics and Management 30(3), 265-281. 
Vogel, D. (1995). Trading Up: Consumer and Environmental Regulation in a Global Economy. Cambridge and London: Harvard University Press.

Wang, Z. and L. Winters (2001). Carbon taxes and industrial location: Evidence from the multinationals literature. In A. Ulph (Ed.), Environmental policy, international agreements, and international trade. Oxford University Press.

Wilson, J. (1996). Capital mobility and environmnental standards: Is there a theoretical basis for a race to the bottom? In J. N. Bhagwati and R. E. Hudec (Eds.), Capital Mobility and Environmnental Standards: Is There a Theoretical Basis for a Race to the Bottom?, Cambridge, Mass. MIT Press. 